\title{
PON2 Gene
}

National Cancer Institute

\section{Source}

National Cancer Institute. PON2 Gene. NCI Thesaurus. Code C113555.

This gene may play a role as a cellular antioxidant. 